\title{
Feeding habits and dietary overlap during the larval development of two sandperches (Pisces: Pinguipedidae)
}

\author{
Javier A. Vera-Duarte, Mauricio F. Landaeta \\ Laboratorio de Ictioplancton (LABITI), Facultad de Ciencias del Mar y de Recursos Naturales, Universidad de Valparaíso, \\ Avenida Borgoño 16344, Reñaca, Viña del Mar, Chile. \\ (JAV-D) E-mail: j.j.vera.duarte@gmail.com. ORCID-iD: http://orcid.org/0000-0002-0539-1245 \\ (MFL) (Corresponding author) E-mail: mauricio.landaeta@uv.cl. ORCID-iD: http://orcid.org/0000-0002-5199-5103
}

\begin{abstract}
Summary: Two species of sandperch (Pinguipedidae: Perciformes), Prolatilus jugularis and Pinguipes chilensis, inhabit the coastal waters of the South Pacific. Both species have pelagic larvae with similar morphology, but their diet preferences are unknown. Diet composition, feeding success, trophic niche breadth and dietary overlap were described during larval stages for both species. In the austral spring, larval $P$. jugularis (3.83-10.80 mm standard length $[\mathrm{SL}])$ and $P$. chilensis (3.49-7.71 $\mathrm{mm} \mathrm{SL}$ ) during their first month of life had a high feeding incidence $(>70 \%)$ and fed mostly on copepod nauplii ( $>80 \%$ IRI), Rhincalanus nasutus metanauplii and Paracalanus indicus copepodites. The number of prey ingested was low (mean: 4-5 prey per gut) and independent of larval size; total prey volume and maximum prey width increased as larvae grew. Mouth opening and ingested prey were greater in larval $P$. jugularis than in $P$. chilensis, leading to significant differences in prey composition among larval species, in terms of prey number and volume. Pearre's trophic niche breadth was narrow for both species $(0.159 \pm 0.07$ for $P$. jugularis; $0.156 \pm 0.03$ for $P$. chilensis $)$ and independent of larval size. Dietary overlap was high inter- and intra-species in larvae with a mouth gape $<900 \mu \mathrm{m}$. These results suggest the relative importance of both larval species as primary consumers of the pelagic web in nearshore environments of rocky temperate areas.
\end{abstract}

Keywords: Prolatilus jugularis; Pinguipes chilensis; sandperch, feeding; resource partitioning; Chile.

Hábitos alimentarios y superposición de la dieta durante el desarrollo larval de dos blanquillos (Pisces: Pinguipedidae)

Resumen: Existen dos especies de blanquillo (Pinguipedidae: Perciformes), Prolatilus jugularis y Pinguipes chilensis que habitan las aguas costeras del Pacífico Sur. Ambas especies tienen larvas pelágicas con morfología similar, pero se desconocen sus preferencias de la dieta. Se describen la composición de la dieta, amplitud del nicho trófico y superposición trófica durante los estados larvales de ambas especies. En primavera, las larvas de P. jugularis (3.83-10.80 mm LE) y P. chilensis (3.49-7.71 mm LE) durante su primer mes de vida tienen alta incidencia alimentaria ( $>70 \%)$ y se alimentan principalmente de nauplii de copépodos (>80\% IRI), metanauplii de Rhincalanus nasutus y copepoditos de Paracalanus indicus. El número de presas ingeridas fue bajo (media: 4-5 presas por estómago) e independiente del tamaño larval; el volumen total de presas y el ancho máximo de las presas se incrementó a medida que crecían las larvas de ambas especies. El largo de la mandíbula y el tamaño de las presas fue más grande en larvas de $P$. jugularis comparado con las de $P$. chilensis. Esto generó diferencias significativas en la composición de las presas entre especies, en términos de número y volumen de las presas ingeridas. La amplitud del nicho trófico de Pearre fue bajo para ambas especies $(0.159 \pm 0.07$ para $P$. jugularis; $0.156 \pm 0.03$ para $P$. chilensis) e independiente del tamaño larval. La superposición dietética fue alta inter e intra-especies en aquellas larvas con apertura bucal $<900 \mu \mathrm{m}$. Estos resultados sugieren la importancia relativa de ambas especies como consumidores primarios de la trama pelágica en ambientes costeros con arrecifes rocosos.

Palabras clave: Prolatilus jugularis; Pinguipes chilensis; blanquillo, alimentación; partición de recursos; Chile.

Citation/Como citar este artículo: Vera-Duarte J.A., Landaeta M.F. 2017. Feeding habits and dietary overlap during the larval development of two sandperches (Pisces: Pinguipedidae). Sci. Mar. 81(2): 195-204. doi: http://dx.doi.org/10.3989/scimar.04544.06A

Editor: D. Vaqué.

Received: September 2, 2016. Accepted: March 9, 2017. Published: April 28, 2017.

Copyright: () 2017 CSIC. This is an open-access article distributed under the terms of the Creative Commons Attribution (CC-by) Spain 3.0 License. 


\section{INTRODUCTION}

The family Pinguipedidae is represented in South America by three endemic genera (Pinguipes, Prolatilus and Pseudopercis) and a single species of Parapercis. Along the Pacific coasts of South America, two species coexist: Pacific sandperch, Prolatilus jugularis (Valenciennes, 1833) and Chilean sandperch Pinguipes chilensis Valenciennes, 1833 (Rosa and Rosa 1997). P. jugularis is distributed from Huacho, Peru $\left(11^{\circ} 11^{\prime} \mathrm{S}\right)$ to Chiloé, Chile $\left(43^{\circ} 43^{\prime} \mathrm{S}\right)$, while $P$. chilensis is distributed from Tumbes, Peru $\left(3^{\circ} \mathrm{S}\right)$, to the Magellan Strait $\left(54^{\circ} \mathrm{S}\right)$. Both species inhabit rocky and sandy bottoms ranging from 0 to $40 \mathrm{~m}$ depth; adults dwell in rocky-bottom areas and juveniles in sandy-bottom areas (Moreno and Zamorano 1980). Pinguipes chilensis feed on a large number of prey taxa, such as crustaceans (mostly mysids), polychaetes and small fish (González and Oyarzún 2003), while P. jugularis feed mainly on benthic and demersal organisms in which sedentary polychaetes and, to a lesser extent, crustaceans are the main prey (Meléndez 1989). Larvae are pelagic and transformation (i.e. the changes in general form and structural detail that involve the acquisition of adult characters and loss of larval characters, Moser 1996) occurs around 11-26 mm (Vélez et al. 2003). However, no information is available about the diet preferences of both species during the larval stages.

For fish populations, resource partitioning involves the exploitation of different dimensions of the niche to reduce competition through the evolution of resourcebased polymorphisms (Lecomte and Dodson 2005). The differences involve three main dimensions, space, food and time, although in studies of fish, segregation through food has been viewed as one of the most important (Ross 1986, Corrêa et al. 2009). Differences in internal and external morphology and foraging modes may also increase tolerance to niche overlap and may reduce the pressure of competition between ecologically similar species (Loy et al. 2001, Frederich et al. 2008, Russo et al. 2008). Therefore, correlating morphology and resource utilization is the first step in illustrating the existence of resource polymorphism among species (Lecomte and Dodson 2005).

During the early ontogeny of fishes, individuals are still developing their foraging capabilities, and prey may be abundant but distributed as patches (Genin et al. 2004). There is little evidence of competition during the larval development of fish larvae (Gisbert et al. 1996), but most of the evidence suggest high dietary niche overlap among larval fish species, between and within cohorts (Mark et al. 1987, Gaughan and Potter 1997, Balbontín et al. 1997). This suggests the importance of random food selection in these early stages, but it is important to study the mechanistic processes causing the resource partitioning through ontogeny. Nonetheless, several studies (Rowlands et al. 2008, Salas-Berríos et al. 2013) have reported a decreasing trend in diet overlap through ontogeny.

The main goal of this work is to describe the feeding habits and trophic niche breadth of the larval stages of two endemic sandperches of the family Pinguipedidae

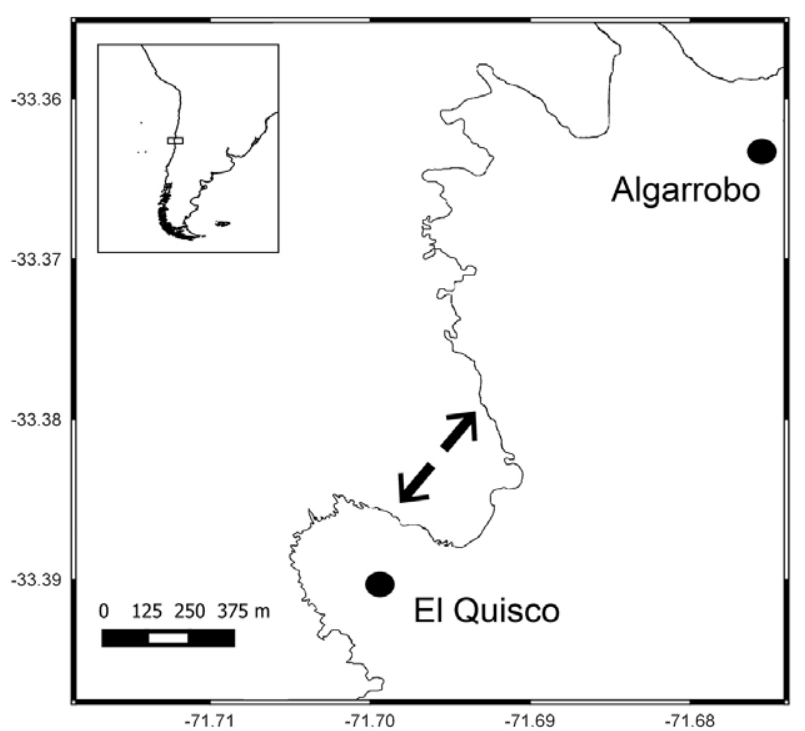

Fig 1. - Map of the study area off El Quisco Bay, central Chile, southeast Pacific.

inhabiting coastal waters of central Chile, and to quantify trophic niche overlap during their larval development. As a working hypothesis, it is expected that high diet overlap occurs between these two marine fishes. The predictions are that i) during larval development, both species feed on similar prey items; ii) both species ingest a similar prey size; and iii) diet niche overlap decreases during development.

\section{MATERIALS AND METHODS}

\section{Field work}

During the late austral winter and spring of 20102012, 13 dusk and nocturnal coastal surveys (1930 to $2300 \mathrm{~h})$ were conducted at El Quisco Bay $\left(33^{\circ} 24^{\prime} \mathrm{S}\right.$, $71^{\circ} 43^{\prime} \mathrm{W}$ ) on board an artisanal vessel (Fig. 1). Oblique hauls of a Bongo net $(60 \mathrm{~cm}$ diameter, $300 \mu \mathrm{m}$ mesh size) with one TSK flowmeter mounted in the frame of the net were performed for 15-20 min from a depth of $20 \mathrm{~m}$. Seawater filtered by the net ranged from 13.1 to $437.4 \mathrm{~m}^{3}$ (mean \pm one standard deviation: $141.7 \pm 102.5$ $\left.\mathrm{m}^{3}\right)$. Subsequently, the nets were washed on board and all zooplankton samples $(n=166)$ were initially fixed with $5 \%$ formalin buffered with sodium borate and preserved in $96 \%$ ethanol after $12 \mathrm{~h}$. Although there are no formal studies about reproduction seasonality of the two species, the period of study was selected during a season when abundance of larval stages of both species is conspicuous and greater than in other seasons (Hernández-Miranda et al. 2003).

\section{Laboratory work}

All fish larvae from plankton samples were separated, counted and identified. Larval Pacific sandperch $P$. jugularis were identified according to features described by Vélez et al. (2003), and Chilean sandperch $P$. chilensis were identified following Neira et al. (1998). Both larvae have a robust body with a large 


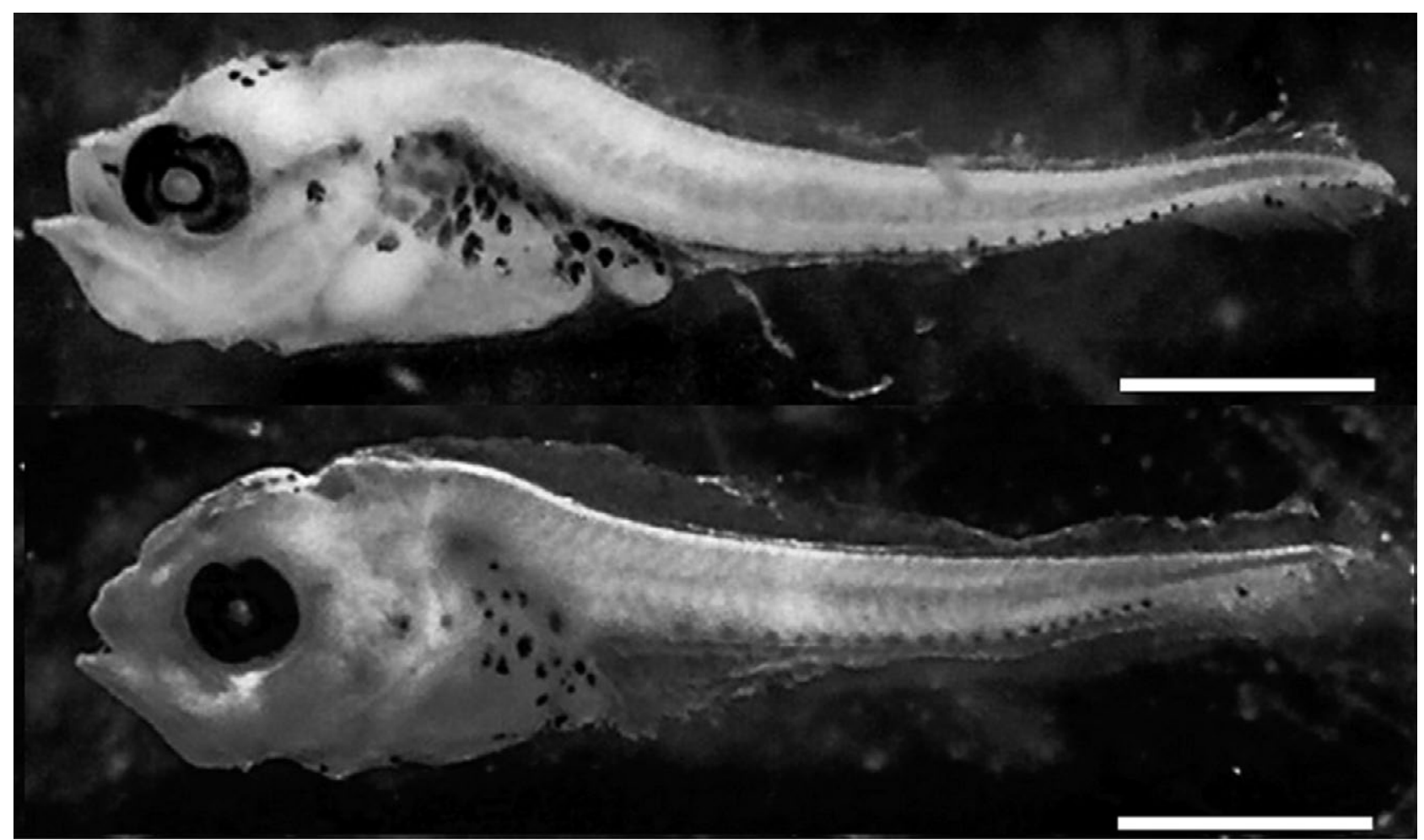

Fig 2. - Larval stages of sandperch collected off El Quisco Bay. Upper, Prolatilus jugularis; Lower, Pinguipes chilensis. White bars correspond to $1 \mathrm{~mm}$ length.

head bearing small preopercular spines; they differ in the presence (absence) of internal melanophores behind the nape in larval $P$. jugularis ( $P$. chilensis) (Fig. 2). Abundance was standardized to individuals per $1000 \mathrm{~m}^{3}$, taking into account the number of larvae captured and volume of the seawater filtered by the net. Standard length (SL) and upper jaw length (UJL, from the tip of the snout to the posterior end of the maxilla) of all intact larval $P$. chilensis and $P$. jugularis $(\mathrm{n}=159$ and 83, respectively) were measured under an Olympus SZ61 stereomicroscope attached to a camera (Motic moticam 2500, resolution 5.0 MPixel) using Motic Image Plus 2.0 software.

The gut of each larva was dissected from the body and opened lengthwise with fine needles. Prey items were counted and identified to the lowest possible taxon, except for indigestible prey remains such as setae, under a Motic BA310 microscope. The maximum SL and width of each prey item (maximum prey width, MPW) were measured with the microscope and a Motic moticam 2500 camera (resolution 5.0 megapixels) using the Motic Image Plus 2.0 software. The volume of each prey item was estimated using the three-dimensional shape that most closely resembled the item, following Cass-Calay (2003) and Sun and Liu (2003). The prosome length of copepodite prey was measured because the urosome was often missing.

\section{Data and statistical analysis}

The relationships between the SL and UJL of the larvae and between the UJL and MPW were determined separately for each species by linear regression analyses, and comparisons of adjusted means were performed with one-way ANCOVA (Zar 1999).

Feeding incidence (FI) was calculated as a percentage of the total number of larvae that had any gut content out of the total number of larvae examined for each species and for larval size ranges. Comparisons of FI among size ranges and between species were carried out with contingency tables.

All larvae with identifiable prey in their guts were used for the analysis. The diet was described using the percentage frequency of occurrence $(\% \mathrm{~F})$ of a diet item in larvae with food in their guts, the percentage of the total number $(\% \mathrm{~N})$ of diet items that were examined and the percentage of volume $(\% \mathrm{~V})$ of each item out of the total volume of prey items. An index of relative importance (IRI) was calculated as $\mathrm{IRI}=(\% \mathrm{~N}+\% \mathrm{~V}) \times \% \mathrm{~F}$. To readily allow comparisons among prey items, the IRI was standardized to \%IRI for each prey item $i$ (Cortés 1997).

To estimate the feeding success of larvae during their development, three measures were compared: number of prey items per gut (NPPG, number), MPW $(\mathrm{mm})$ and total prey volume per gut (TPVG, $\mathrm{mm}^{3}$ ) (Reiss et al. 2002, Landaeta et al. 2011). To determine whether these indicators of feeding success were related to the growth of larvae, non-parametric correlation tests were run (Spearman rank tests, rs); if correlation was significant $(\mathrm{P}<0.05)$, then the feeding success was related to the larval size, and simple linear regressions were carried out between indicators (NPPG, MPW, and TPVG) and SL for both larval species. In order to compare the feeding success between species, one-way ANCOVAs were run if parameters 
Table 1. - Linear regression models for the relationship between standard length (SL) and upper jaw length (UJL). SE, standard error.

\begin{tabular}{lccccccc}
\hline Species & Intercept $(\mu \mathrm{m})$ & $\mathrm{SE}$ & Slope $\left(\mu \mathrm{m} \mathrm{mm}^{-1}\right)$ & $\mathrm{SE}$ & $\mathrm{R}^{2}$ & $\mathrm{~F}$ & $\mathrm{P}$ \\
\hline Prolatilus jugularis & -396.12 & 88.83 & 183.52 & 14.39 & 0.667 & 167.47 & $<0.001$ \\
Pinguipes chilensis & -422.57 & 17.26 & 175.77 & 3.04 & 0.955 & 3339 & $<0.001$ \\
\hline
\end{tabular}

were significantly correlated with SL. If not, a MannWhitney U-test was run.

To compare feeding composition among larval species and size groups, in terms of prey number and volume, two-way PERMANOVAs were run, using the Bray-Curtis similarity index and 9999 permutations, with Past 3.13 software (Hammer et al. 2001).

Intraspecific differences in prey size were examined throughout larval development. Pearre's trophic niche breadth (Pearre 1986) was adopted to analyse the relationship between prey size and predator size. This model uses the standard deviation (SD) of the $\log _{10}$-transformed prey size as a measure of trophic niche breadth. In this analysis, fish larvae were classified according to body length at $0.1-\mathrm{mm}$ intervals. Only classes with $>2$ prey item in the gut were used for further analysis. The mean and SD of the $\log _{10^{-}}$ transformed prey width was calculated for each available size class of larval fish. The relationship between body length and the corresponding mean and SD of the $\log _{10}$-transformed prey size was examined using linear regression analysis to determine any shifts in niche breadth with growth.

Diet overlap between larval $P$. jugularis and $P$. chilensis was measured using Schoener's overlap index $\alpha$ (Schoener 1970), a robust measure of diet similarity (Wallace 1981): $\alpha=1-0.5 \Sigma\left|\mathrm{P}_{\mathrm{xi}}-\mathrm{P}_{\mathrm{yi}}\right|$, where $\mathrm{P}_{\mathrm{xi}}$ and $\mathrm{P}_{\mathrm{yi}}$ are the frequencies of prey category $\mathrm{i}$ in predator species $x$ and $y$. Index value ranges from 0 (no overlap) to 1 (complete overlap), and overlap, in general, is considered to be biologically significant when the value is $>0.6$ (Schoener 1970, Keast 1978). Where species differ markedly in their diet, overlap levels will be low; however, where common items make up a significant percentage of the diet of the two species, they will be high, and (theoretically) the species will be in potential competition (Keast 1978). Comparisons were made for similar size ranges of the upper jaw length: $<300,300-$ 500, 500-700, 700-900 and >900 $\mu \mathrm{m}$ UJL.

\section{RESULTS}

\section{Morphometric measurements and body size}

For the two larval species, size range was similar, varying from 3.83 to $10.80 \mathrm{~mm}$ SL for $P$. jugularis (mean \pm standard error, median; $5.58 \pm 0.07 \mathrm{~mm}, 5.61$ $\mathrm{mm}$ ), and from 3.49 to $7.71 \mathrm{~mm}$ SL for P. chilensis $(6.02 \pm 0.14 \mathrm{~mm}, 6.00 \mathrm{~mm})$. Similarly, the UJL of the two larval species was similar in range, 259.4-1485.50 $\mu \mathrm{m}$ for $P$. jugularis and 256.00-1066.60 $\mu \mathrm{m}$ for $P$. chilensis. For both species, the relationship between SL and UJL was linear, showing larger variability in $P$. jugularis $\left(\mathrm{R}^{2}=0.667\right)$ than in $P$. chilensis $\left(\mathrm{R}^{2}=0.955\right.$, Table 1, Fig. 3). The latter may be due to greater variation in the allometric growth of mouth gape and snout in larval $P$. jugularis (Vélez et al. 2003). For larval $P$. jugularis, mouth gape corresponded to $5.9 \%$ to $19.1 \%$ SL (mean \pm SD, $11.4 \pm 3.2 \%$ SL), while in larval $P$. chilensis, mouth opening corresponded to $6.9 \%$ to $13.8 \%$ SL $(9.7 \pm 1.5 \%$ SL). In the comparison of UJL of the two species (corrected by body length and for the same size range, 3-8 $\mathrm{mm}$ ), larval $P$. jugularis had a larger mouth gape than $P$. chilensis (one-way ANCOVA, $\mathrm{F}=23.29$; $\mathrm{P}<0.001$ ), and both increased their gape through development at similar rates, $175-183 \mu \mathrm{m} \mathrm{mm}^{-1}$ (homogeneity of slopes, $\mathrm{F}=0.39 ; \mathrm{P}=0.531$, Table 1 ).

\section{Feeding incidence}

Both species showed high FI throughout their larval development (Fig. 4); empty stomach accounted for 19 out of 159 individuals in larval $P$. chilensis and 6 out of 83 individuals in larval $P$. jugularis. FI varied from $81.8 \%$ to $100 \%$ in larval $P$. jugularis, and from $69.2 \%$ to $100 \%$ in $P$. chilensis. There was no significant difference in the FI between species $\left(\chi^{2}=1.63, \mathrm{P}=0.202\right)$, or among size ranges for larval $P$. jugularis $\left(\chi^{2}=5.01\right.$, $\mathrm{P}=0.543$ ); however, the largest sizes of larval $P$. chilen-
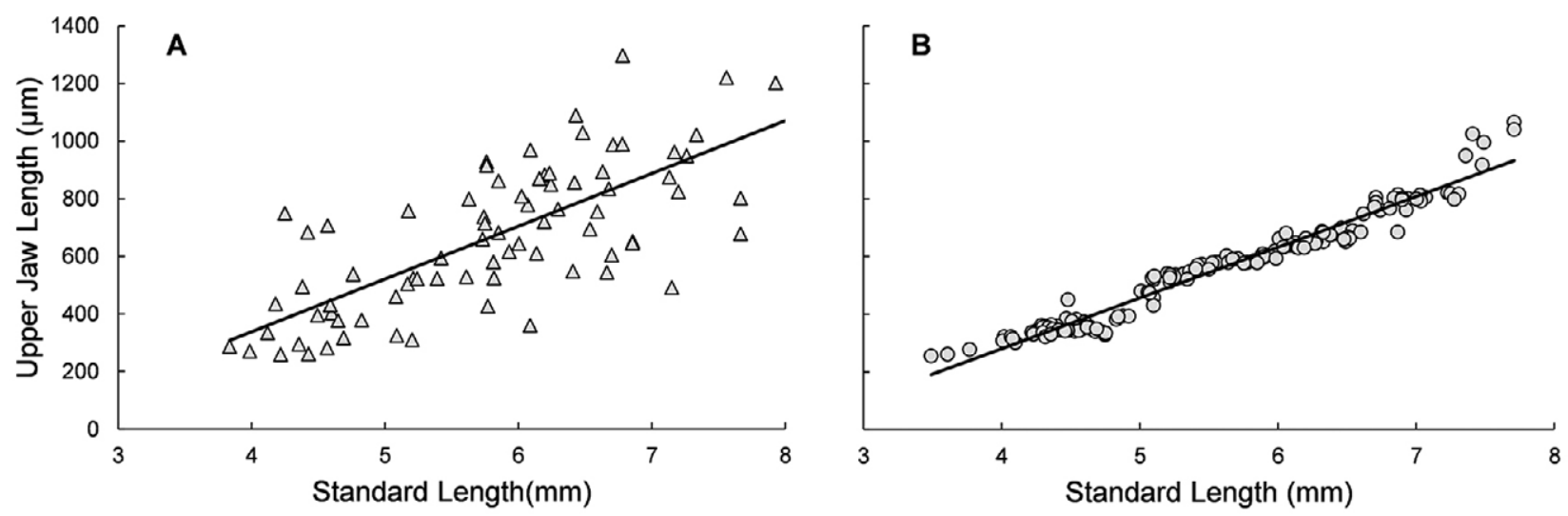

Fig 3. - Relationship between standard length (mm) and upper jaw length ( $\mu \mathrm{m})$ for larval sandperch. Left panel, Prolatilus jugularis (triangles); right panel, Pinguipes chilensis (circles). 


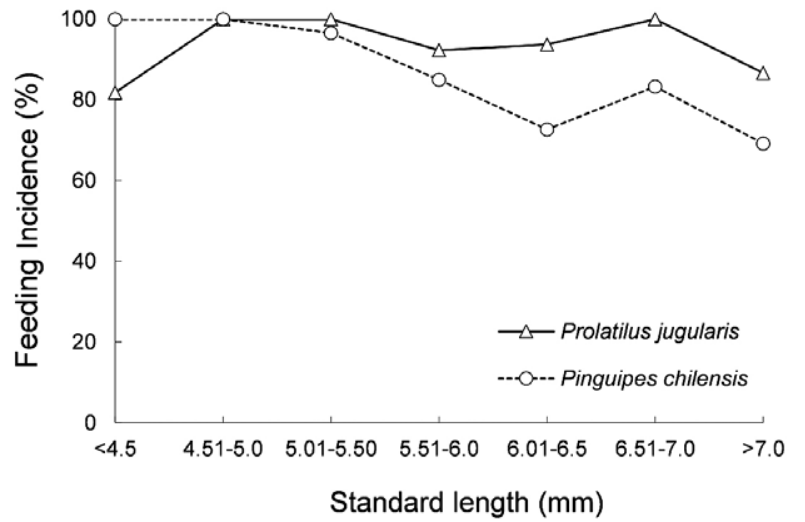

Fig 4. - Feeding incidence throughout larval development of sandperches Prolatilus jugularis and Pinguipes chilensis. sis showed a significant decrease in FI during development $\left(\chi^{2}=19.7, \mathrm{P}=0.003\right)$.

\section{Diet composition in larval sandperch}

The diet composition of $P$. jugularis and $P$. chilensis was similar (22 and 24 prey items), dominated mainly by copepod nauplii, followed by calanoid copepodites, calyptopes, invertebrate eggs, zoea and early stages of gasteropods and polychaetes (Table 2 and 3 ).

Nauplii were the most important prey throughout larval development (\%IRI 80\%-90\%, \% F> 70\%), and were numerically important from small to larger larvae $(80-70 \% \mathrm{~N})$. In terms of $\% \mathrm{~V}$, copepod nauplii items in $P$. jugularis remained constant at $\sim 30 \%$ in larvae of less than $7 \mathrm{~mm}$, but in $P$. chilensis they decreased

Table 2. - Prey composition of Pacific sandperch, P. jugularis, larvae off central Chile. \% $\mathrm{N}$ corresponds to the percent of the total number of prey items, $\% \mathrm{~F}$ to the percent frequency of the occurrence of a diet among larvae with food in their guts, and $\% \mathrm{~V}$ to the percent of the total volume of prey items. \%IRI corresponds to the index of relative importance as a percentage.

\begin{tabular}{|c|c|c|c|c|c|c|c|c|c|c|c|c|}
\hline \multirow[b]{2}{*}{ Prey item } & \multicolumn{4}{|c|}{$3-5 \mathrm{~mm}(\mathrm{n}=17)$} & \multicolumn{4}{|c|}{$5-7 \mathrm{~mm}(\mathrm{n}=47)$} & \multicolumn{4}{|c|}{$>7 \mathrm{~mm}(\mathrm{n}=13)$} \\
\hline & $\% \mathrm{~N}$ & $\% \mathrm{~F}$ & $\% \mathrm{~V}$ & $\%$ IRI & $\% \mathrm{~N}$ & $\% \mathrm{~F}$ & $\% \mathrm{~V}$ & $\%$ IRI & $\% \mathrm{~N}$ & $\% \mathrm{~F}$ & $\% \mathrm{~V}$ & $\%$ IRI \\
\hline Invertebrate eggs & 5.00 & 17.65 & 5.38 & 1.92 & 1.67 & 6.38 & 0.90 & 0.17 & - & - & - & \\
\hline Tintinnid & - & - & - & & - & - & - & & 4.35 & 12.50 & 0.86 & 0.85 \\
\hline Gasteropod larvae & - & - & - & & 0.56 & 2.13 & 0.13 & 0.02 & - & - & - & \\
\hline Trocophore larvae & - & - & - & & 0.56 & 2.13 & 0.84 & 0.03 & - & - & - & \\
\hline Cypris larvae & 1.25 & 5.88 & 1.63 & 0.18 & 1.67 & 6.38 & 8.74 & 0.69 & - & - & - & \\
\hline Oikopleura sp. & 2.50 & 11.76 & 0.99 & 0.43 & 1.67 & 6.38 & 6.98 & 0.57 & - & - & - & \\
\hline Zoea Brachyura & - & - & - & & 0.56 & 2.13 & 0.55 & 0.02 & - & - & - & \\
\hline Copepod eggs & 1.25 & 5.88 & 5.22 & 0.40 & - & - & - & & - & - & - & \\
\hline Nauplii & 83.75 & 76.47 & 32.90 & 93.37 & 78.33 & 80.85 & 32.84 & 93.14 & 73.91 & 75.00 & 8.12 & 80.67 \\
\hline Metanauplii (Rhincalanus nasutus) & - & - & - & & - & - & - & & 4.35 & 12.50 & 4.38 & 1.43 \\
\hline Copepodite & - & - & - & & 3.89 & 12.77 & 6.78 & 1.41 & 4.35 & 12.50 & 6.20 & 1.73 \\
\hline Acartia tonsa & 1.25 & 5.88 & 1.95 & 0.20 & 1.11 & 4.26 & 4.92 & 0.27 & - & - & - & \\
\hline Calanoides patagoniensis & - & - & - & & 0.56 & 2.13 & 0.48 & 0.02 & - & - & - & \\
\hline Calanus chilensis & 1.25 & 5.88 & 16.46 & 1.09 & 0.56 & 2.13 & 0.41 & 0.02 & - & - & - & \\
\hline Clausocalanus arcuicornis & - & - & . & & 1.11 & 4.26 & 2.61 & 0.16 & 4.35 & 12.50 & 2.33 & 1.09 \\
\hline Metridia luticens & - & - & & & 0.56 & 2.13 & 5.58 & 0.14 & - & - & - & \\
\hline Paracalanus indicus & 1.25 & 5.88 & 2.25 & 0.22 & 3.33 & 12.77 & 13.38 & 2.21 & 4.35 & 12.50 & 4.55 & 1.46 \\
\hline Euphausiid eggs & 1.25 & 5.88 & 4.95 & 0.38 & 1.67 & 4.26 & 1.32 & 0.13 & - & - & - & \\
\hline Calyptopis (Euphausia mucronata) & 1.25 & 5.88 & 28.26 & 1.82 & 1.67 & 6.38 & 13.14 & 0.98 & - & - & - & \\
\hline Myses of Callianassidae & - & - & - & & 0.56 & 2.13 & 0.39 & 0.02 & - & - & - & \\
\hline Fish eggs & - & - & - & & - & - & - & & 4.35 & 12.50 & 73.56 & 12.77 \\
\hline
\end{tabular}

Table 3. - Prey composition of sandperch Pinguipes chilensis larvae off central Chile. \%N corresponds to the percent of the total number of prey items, $\% \mathrm{~F}$ to the percent frequency of the occurrence of a diet among larvae with food in their guts, and $\% \mathrm{~V}$ to the percent of the total volume of prey items. \%IRI corresponds to the index of relative importance as a percentage.

\begin{tabular}{|c|c|c|c|c|c|c|c|c|c|c|c|c|}
\hline \multirow{2}{*}{ Prey item } & \multicolumn{4}{|c|}{$3-5 \mathrm{~mm}(\mathrm{n}=51)$} & \multicolumn{4}{|c|}{$5-7 \mathrm{~mm}(\mathrm{n}=79)$} & \multicolumn{4}{|c|}{$>7 \mathrm{~mm}(\mathrm{n}=10)$} \\
\hline & $\% \mathrm{~N}$ & $\% \mathrm{~F}$ & $\% \mathrm{~V}$ & $\%$ IRI & $\% \mathrm{~N}$ & $\% \mathrm{~F}$ & $\% \mathrm{~V}$ & $\%$ IRI & $\% \mathrm{~N}$ & $\% \mathrm{~F}$ & $\% \mathrm{~V}$ & $\%$ IRI \\
\hline Invertebrate eggs & 2.52 & 11.76 & 7.25 & 1.00 & 4.11 & 13.92 & 7.18 & 1.95 & 3.85 & 20.00 & 10.64 & 2.94 \\
\hline Gasteropod larvae & - & - & - & & 0.59 & 2.53 & 1.12 & 0.05 & - & - & - & \\
\hline Polychaeta larvae & - & - & - & & 1.17 & 2.53 & 0.33 & 0.05 & - & - & - & \\
\hline Cypris larvae & 0.84 & 3.92 & 1.14 & 0.07 & 0.29 & 1.27 & 0.06 & 0.01 & - & - & - & \\
\hline Balanidae larvae & 0.42 & 1.96 & 0.56 & 0.02 & 0.29 & 1.27 & 0.25 & 0.01 & - & - & - & \\
\hline Trocophore larvae & 2.52 & 3.92 & 1.48 & 0.14 & - & - & - & & - & - & - & \\
\hline Ostracoda & - & - & - & & 0.29 & 1.27 & 1.84 & 0.03 & - & - & - & \\
\hline Prezoea & 1.68 & 5.88 & 3.24 & 0.25 & 0.59 & 2.53 & 0.27 & 0.03 & - & - & - & \\
\hline Zoea Paguridae & - & - & - & & 0.29 & 1.27 & 5.80 & 0.10 & - & - & - & \\
\hline Zoea Porcelanidae & 0.42 & 1.96 & 0.97 & 0.02 & - & - & - & & - & - & - & \\
\hline Nauplii & 80.67 & 78.43 & 61.30 & 96.56 & 68.62 & 72.15 & 30.60 & 88.76 & 67.31 & 80.00 & 30.92 & 79.68 \\
\hline Metanauplii (Rhincalanus nasutus) & 3.78 & 11.76 & 8.10 & 1.21 & 3.23 & 8.86 & 4.05 & 0.80 & 9.62 & 30.00 & 18.35 & 8.51 \\
\hline Copepodite & 1.68 & 3.92 & 2.59 & 0.15 & 2.64 & 10.13 & 3.88 & 0.78 & 3.85 & 20.00 & 6.72 & 2.14 \\
\hline Acartia tonsa & 1.26 & 3.92 & 3.38 & 0.16 & 2.35 & 10.13 & 6.31 & 1.09 & 1.92 & 10.00 & 0.94 & 0.29 \\
\hline Aetideus armatus & 1.26 & 5.88 & 0.71 & 0.10 & 0.29 & 1.27 & 2.37 & 0.04 & 1.92 & 10.00 & 4.01 & 0.60 \\
\hline Calanus chilensis & 0.42 & 1.96 & 4.24 & 0.08 & 1.17 & 5.06 & 5.25 & 0.40 & 1.92 & 10.00 & 15.16 & 1.73 \\
\hline Centropages brachiatus & - & - & - & & 0.29 & 1.27 & 4.40 & 0.07 & - & - & - & \\
\hline Corycaeus sp. & - & - & - & & 0.59 & 0.03 & 0.81 & 0.04 & - & - & - & \\
\hline Metridia longa & - & - & - & & 0.88 & 3.80 & 4.89 & 0.27 & - & - & - & \\
\hline Oncaea sp. & - & - & - & & 0.59 & 2.53 & 1.58 & 0.07 & - & - & - & \\
\hline Paracalanus indicus & 1.26 & 3.92 & 2.45 & 0.13 & 5.28 & 17.72 & 9.17 & 3.18 & 3.85 & 20.00 & 5.98 & 1.99 \\
\hline Pleuromamma gracilis & 0.84 & 3.92 & 2.52 & 0.11 & 0.29 & 1.27 & 0.34 & 0.01 & 1.92 & 10.00 & 3.33 & 0.53 \\
\hline Harpacticoid copepodite & - & - & - & & 1.17 & 5.06 & 4.20 & 0.34 & - & - & - & \\
\hline Calyptopis (Euphausia mucronata) & 0.42 & 1.96 & 0.09 & 0.01 & 4.99 & 15.19 & 5.27 & 1.93 & 3.85 & 20.00 & 3.94 & 1.58 \\
\hline
\end{tabular}



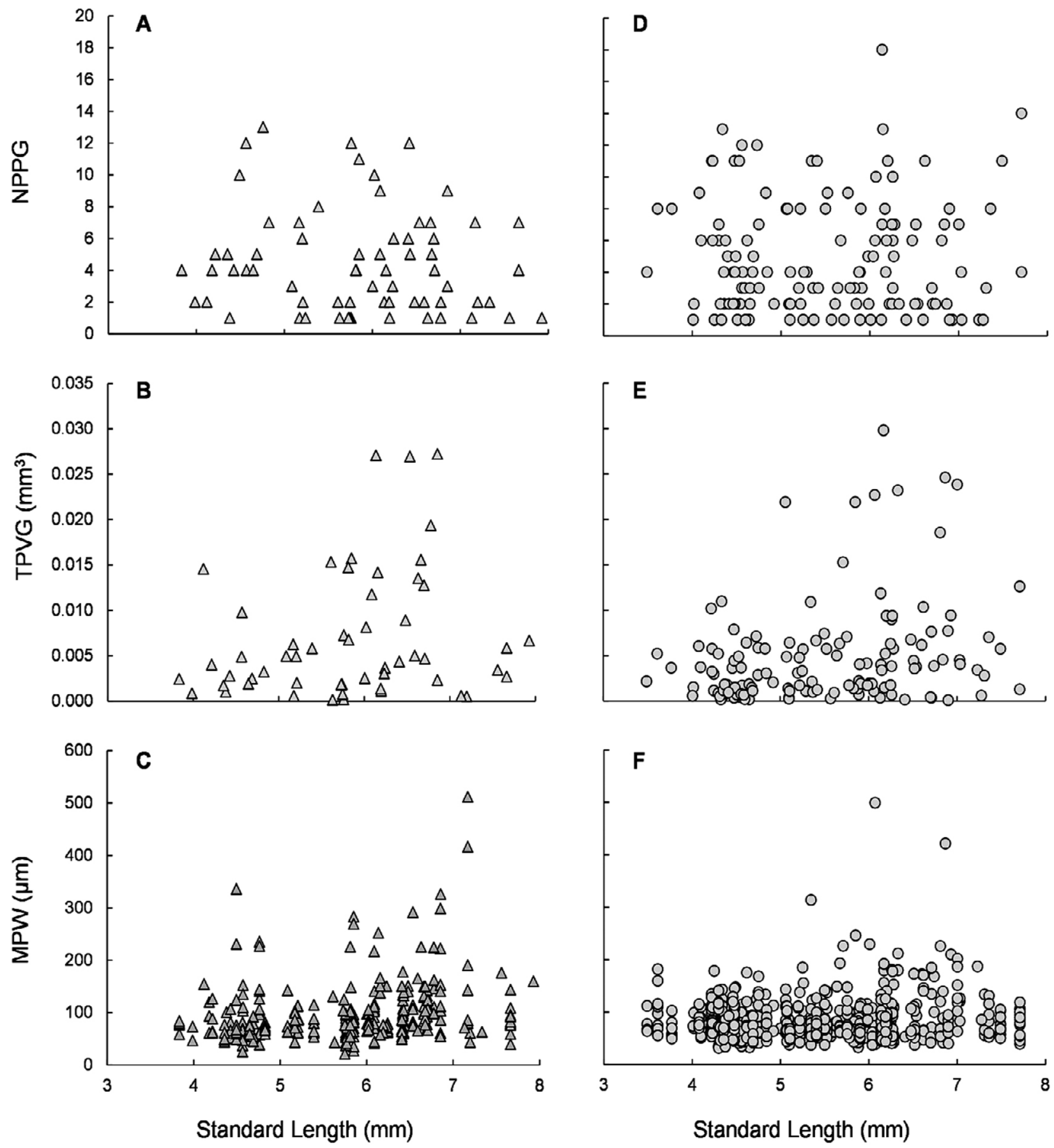

Fig 5. - Feeding success of larval sandperch measured as number of prey per gut (NPPG, number), total volume per gut $\left(\mathrm{TVPG}, \mathrm{mm}^{3}\right)$ and maximum prey width (MPW, $\mu \mathrm{m})$, and its variation with standard length (mm). Left panels, Prolatilus jugularis (triangles); right panel, Pinguipes chilensis (circles).

from small larvae to large larvae. In the gut contents of $P$. jugularis, tintinnids, appendicularians, Calanoides patagoniensis, Clausocalanus arcuicornis, Metridia lucens, euphausiid eggs, myses and fish eggs were also identified (Table 2). In the case of $P$. chilensis, they fed on balanidae larvae, polychaeta larvae and copepodites of Aetideus armatus, Centropages brachiatus, Corycaeus sp., Oncaea sp. and Pleuromamma gracilis (Table 3). Numerically and volumetrically, copepodites were slightly more important than egg items. In terms of $\% \mathrm{~F}$, in both diets the most important items were nauplii, invertebrate eggs and Paracalanus indicus. Finally, both diets had similar prey items, such as gasteropod larvae, zoea and some copepodites such as Acartia tonsa, Calanus chilensis and Metridia longa (Table 2 and 3 ).

\section{Feeding success}

Throughout the larval development, the NPPG was low, varying between 1 and 13 prey (mean \pm SD, 4.2 \pm 3.1 prey per gut) in $P$. jugularis and between 1 
Table 4. - Two-way PERMANOVA results of larval sandperch. A, prey number per gut; $\mathrm{B}$, prey volume per gut. Bold numbers indicate significant $(\mathrm{P}<0.05)$ effect.

\begin{tabular}{lccccc}
\hline Source & SS & df & MS & pseudo F & P \\
\hline A & 1.90 & 1 & 1.90 & 1.22 & $\mathbf{0 . 0 0 0 4}$ \\
Species & 2.25 & 2 & 1.12 & 0.72 & 0.3272 \\
Size Group & -106.24 & 2 & -53.12 & -34.16 & 0.7571 \\
Interaction & 300.09 & 193 & 1.55 & & \\
Residual & 198 & 198 & & & \\
Total & & & & & P \\
B & 1.84 & 1 & 1.84 & 1.22 & $\mathbf{0 . 0 0 0 7}$ \\
Species & 2.31 & 2 & 1.16 & 0.77 & 0.2158 \\
Size Group & -96.95 & 2 & -48.48 & -32.17 & 0.5691 \\
Interaction & 290.83 & 193 & 1.51 & & \\
Residual & 198.02 & 198 & & & \\
Total & & & & & \\
\hline
\end{tabular}

and $19(5.5 \pm 3.6)$ in $P$. chilensis. In both species, NPPG was independent of larval size (Spearman $\mathrm{rs}_{\mathrm{Pj}}=-0.14$, $\mathrm{P}=0.080 ; \mathrm{rs}_{\mathrm{Pc}_{\mathrm{c}}}=-0.029, \mathrm{P}=0.732$ ) (Fig. 5A, D).

The total volume per gut (TVPG) ranged from $1.4 \times 10^{-4}$ and $0.027 \mathrm{~mm}^{3}\left(0.008 \pm 0.007 \mathrm{~mm}^{3}\right)$ in $P$. jugularis, while in larval $P$. chilensis it varied from $3.3 \times 10^{-5}$ to $0.031 \mathrm{~mm}^{3}\left(0.007 \pm 0.006 \mathrm{~mm}^{3}\right)$. A significant positive correlation was evident between larval size (SL) and TVPG for both larval sandperches (Spearman $\mathrm{rs}_{\mathrm{PJ}}=0.259, \mathrm{P}<0.01 ; \mathrm{rs}_{\mathrm{PC}}=0.259, \mathrm{P}<0.01$ ) (Fig. 5B, E). No significant differences were detected in TVPG between the two species (one-way ANCOVA, $\mathrm{F}=2.59$, $\mathrm{P}=0.109$ ) (range of comparison, 3-8 mm SL), suggesting that at a given size, total prey volume ingested was equal ( $P$. jugularis $0.006 \mathrm{~mm}^{3} ; P$. chilensis $0.004 \mathrm{~mm}^{3}$ ) (homogeneity of slope test, $\mathrm{F}=2 \times 10^{-4}, \mathrm{P}=0.987$ ).

MPW ranged between 21.55 and $511.3 \mu \mathrm{m}$ $(105.1 \pm 64.5 \mu \mathrm{m})$ in $P$. jugularis, and between 31.4 and $499 \mu \mathrm{m}(82.4 \pm 41.7 \mu \mathrm{m})$ in $P$. chilensis. In both species, MPW was positively correlated with larval length
(SL) (Spearman $\quad \mathrm{rs}_{\mathrm{PJ}}=0.417, \quad \mathrm{P}<0.01 ; \quad \mathrm{rs}_{\mathrm{PC}}=0.100$, $\mathrm{P}<0.05)$, suggesting that at larger sizes, larvae select larger prey items (Fig. 5C, F). One-way ANCOVA indicates significant differences in the MPW between $P$. jugularis and $P$. chilensis $(\mathrm{F}=17.72, \mathrm{P}<0.01) ; P$. jugularis ingested wider prey $(97.3 \mu \mathrm{m})$ than $P$. chilensis $(83.0 \mu \mathrm{m})$ at the same size (homogeneity of slope test, $\mathrm{F}=9.85, \mathrm{P}<0.001)$.

Two-way PERMANOVA detected significant differences in prey number and volume composition between the larval species (Table 4), but it found no difference among the size ranges analysed within the species $(\mathrm{P}>0.05)$. The latter suggests an absence of differences during the larval development of the two species.

\section{Trophic niche}

Trophic niche breadth (SD of prey size) was narrow and similar between the two larval sandperches. For $P$. jugularis it was $0.159 \pm 0.07$ and for $P$. chilensis it was $0.156 \pm 0.03$ (Fig. 6). In both cases, trophic niche breadth was independent of larval size, as suggested by the linear regressions (Table 5).

\section{Diet overlap}

Schoener's index of diet overlap varied between 0.291 (no overlap) and 0.909 (high diet overlap) $(0.652 \pm 0.183)$ (Table 6). Most of the indices showed a biologically relevant diet overlap, particularly between larvae having an UJL of less than $900 \mu \mathrm{m}$, considering intra- and interspecies comparisons. This suggests that resource partitioning is occurring late in the larval development of both sandperches.
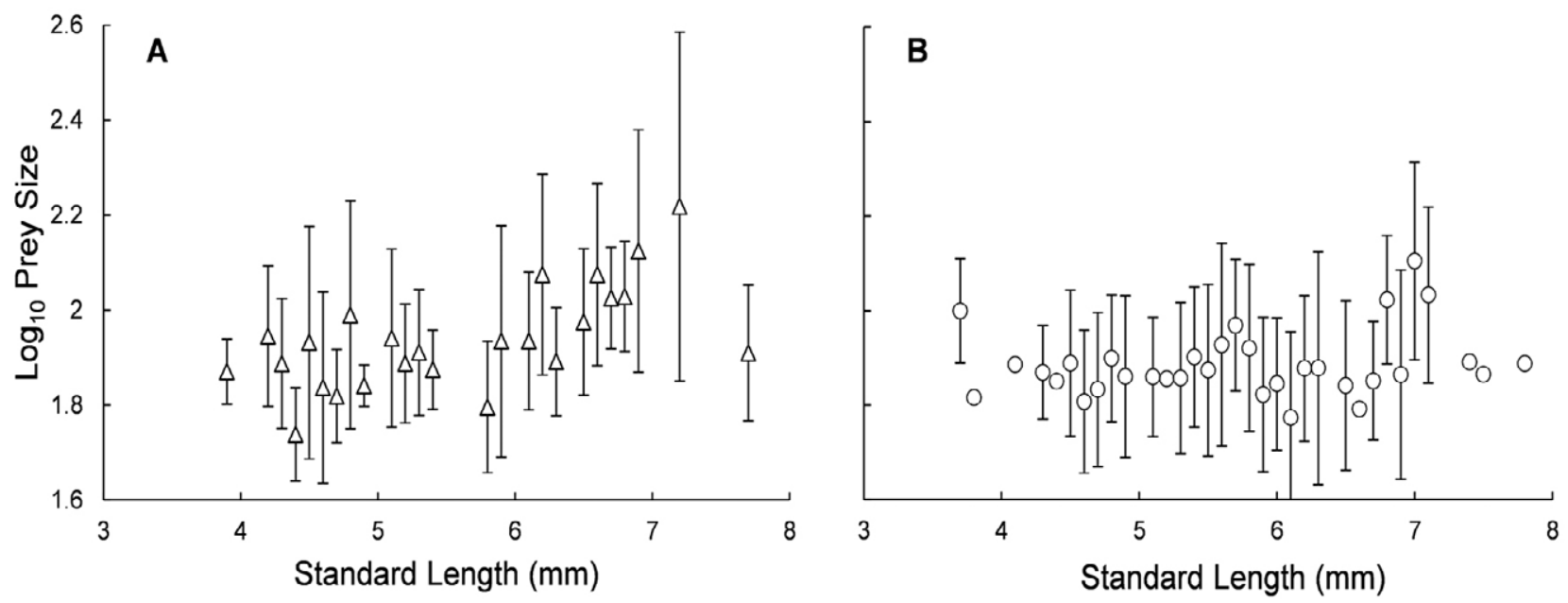

Fig 6. - Prey size and fish body length relationships for larval sandperches. Left panel, Prolatilus jugularis (triangles); right panel, Pinguipes chilensis (circles).

Table 5. - Summary of main results of least square linear regression between Pearre's trophic niche breadth and standard length of each larval sandperch collected on the coast of El Quisco Bay, Chile.

\begin{tabular}{lcccccc}
\hline Model & Intercept & SE & Slope & SE & $\mathrm{R}^{2}$ & P \\
\hline Prolatilus jugularis & 0.038 & 0.077 & 0.022 & 0.013 & 0.102 & 0.121 \\
Pinguipes chilensis & 0.129 & 0.0304 & 0.004 & 0.005 & 0.025 & 0.368 \\
\hline
\end{tabular}


Table 6. - Schoener's dietary niche overlap index among species (Pjug, Prolatilus jugularis; Pchi, Pinguipes chilensis) and upper jaw length ranges $(<300,300-500,500-700,700-900$ and $>900 \mu \mathrm{m})$. Bold numbers indicate biologically relevant niche overlap.

\begin{tabular}{|c|c|c|c|c|c|c|c|c|c|}
\hline & Pjug 300-500 & Pjug 500-700 & Pjug 700-900 & Pjug $>900$ & Pchi $<300$ & Pchi 300-500 & Pchi 500-700 & Pchi 700-900 & Pchi $>900$ \\
\hline Pjug <300 & 0.664 & 0.745 & 0.830 & 0.444 & 0.628 & 0.663 & 0.753 & 0.867 & 0.563 \\
\hline Pjug 300-500 & - & 0.819 & 0.685 & 0.500 & 0.883 & 0.900 & 0.791 & 0.780 & 0.310 \\
\hline Pjug 500-700 & & - & 0.803 & 0.533 & 0.776 & 0.791 & 0.875 & 0.837 & 0.408 \\
\hline Pjug 700-900 & & & - & 0.482 & 0.659 & 0.680 & 0.774 & 0.830 & 0.508 \\
\hline Pjug $>900$ & & & & - & 0.458 & 0.460 & 0.462 & 0.444 & 0.344 \\
\hline Pchi $<300$ & & & & & - & 0.909 & 0.740 & 0.761 & 0.291 \\
\hline Pchi 300-500 & & & & & & - & 0.798 & 0.797 & 0.335 \\
\hline Pchi 500-700 & & & & & & & - & 0.811 & 0.425 \\
\hline Pchi 700-900 & & & & & & & & - & 0.530 \\
\hline Pchi $>900$ & & & & & & & & & - \\
\hline
\end{tabular}

\section{DISCUSSION}

Sandperches of the family Pinguipedidae from the Pacific coast showed similar diet preferences and prey size spectra during their larval development, except for those individuals with a mouth gape larger than 900 $\mu \mathrm{m}$. Feeding of larval sandperches was based mostly on calanoid copepod nauplii and copepodites, but the mean prey size (i.e. width) was slightly, but significantly, larger in guts of larval $P$. jugularis than $P$. chilensis, and the proportion of the mouth gape to body size was larger for $P$. jugularis.

Under a scenario of food limitation, it is expected that larvae and early juveniles compete with the same developmental stages of other species (Rowlands et al. 2008, Walkusz et al. 2015) and with other cohorts of the same species (Bogacka-Kapusta and Kapusta 2014). At high latitudes, for example, during their larval stage, cod, whiting and haddock select nauplii, with a decreasing trend with increasing larval length and developmental stage (Rowlands et al. 2008). In snailfishes of the genus Liparis, three sympatric species prey most on the small cyclopoid copepod Triconia borealis and polychaete larvae (Walkusz et al. 2015). In shallow, polymictic lakes of northern Poland, fish of smaller sizes exploited the same resources as the individuals of the same species belonging to another cohort (Leucaspius delineatus) or individuals with larger body sizes (Perca fluviatilis, Bogacka-Kapusta and Kapusta 2014).

However, under conditions of large prey availability, one can expect high diet overlap but no competition, or a temporal coupling/decoupling in the diet overlap (Dobroslavić et al. 2013). Marine fish larvae from the Humboldt Current System feed on similar prey items, mainly different stages of calanoid copepods (adults, copepodites, nauplii, eggs) (Valenzuela et al. 1995, Llanos-Rivera et al. 2004, Vera-Duarte and Landaeta 2016). In our study, larval sandperches, nauplii and copepodites contributed the largest prey number, volume and frequency. In terms of carbon content, copepodites contribute more than other preys, and the contribution of nauplii is equivalent to $25 \%$ of the carbon contribution of a copepodite, but nauplii contribute the greatest amount of carbon source in pre-flexion stages of fishes from central Chile (Yañez-Rubio et al. 2011).

Larvae of cryptic benthic fishes may also feed particularly on gasteropod larvae and cirripede nauplii (clingfish Sicyases sanguineus, Bernal-Durán and Landaeta 2017) and fish eggs (blenny Auchenionchus variolosus) (Vera-Duarte and Landaeta 2016). The inclusion of these types of prey, and also calyptopes, prezoeae and cypris larvae, may explain variations in prey composition among species of sandperches detected by permutation analysis (PERMANOVA). Beta diversities that encompass differences in the relative abundance of prey can yield useful insights into the specific nature of community-level changes (Anderson et al. 2011), and explain the resemblance of prey composition among coastal fish during their pelagic stages, without causing competition.

The coastal area of central Chile is characterized by seasonal predominance of south winds during the austral spring-summer that favour the occurrence of coastal upwelling events (Sobarzo et al. 2007, Aravena et al. 2014). These events increase the phytoplanktonic biomass, primary and secondary productivity (Henríquez et al. 2007) and copepod diversity (Hidalgo et al. 2012), and sustain a large fishery industry based on both pelagic and demersal species (Arcos et al. 2001). In the Humboldt Current System (HCS), several marine fishes (for example, anchoveta, Castro et al. 2000; hake, Landaeta and Castro 2012) have developed reproductive tactics coupled with physical processes favouring retention within (or drift toward) appropriate habitat, where enrichment and concentration processes also occur (the so-called ocean or Bakun triad, Bakun 2010). The temporal coupling with these processes is a way to reduce mortality by starvation during the firstfeeding period (the match-mismatch hypothesis, Cushing 1990). Sandperch may exploit the available prey resources during their pelagic stages in coastal waters, reducing offshore advection and increasing chances of prey detection and ingestion. The latter was evidenced indirectly by the large percentage of FI and large prey number in both species during larval stages.

The sampling method used in our study (a Bongo net with $300 \mu \mathrm{m}$ mesh size), precludes a correct estimation of the prey field available for fish larvae. Although trophic selectivity cannot be calculated for larval sandperches, estimated abundance of nauplii in the field is around 300-2000 ind. $\mathrm{m}^{-2}$ in coastal waters of central Chile (Giesecke and González 2008) or around 200-4000 ind. $\mathrm{m}^{-3}$ throughout the year (Hidalgo and Escribano 2007), suggesting a lack of competition between larval Prolatilus and Pinguipes in coastal marine environments. Additionally, significant differences in mean prey width among species suggest that they may be predating different naupliar stages and/or species. The digestion of nauplii in the guts and the lack of 
formal descriptions of the nauplii copepods from the HCS prevent us from identifying nauplii to lower taxonomic levels, and this source of error may overestimate trophic overlap.

Morphological variations among species and between populations of the same species may lead to major changes in diet preference. Recently, Costalago et al. (2015) described that the feeding ecology of juveniles and adults of the sardine Sardina pilchardus from two contrasting environments showed clear differences in the feeding apparatus (i.e. number of gill rakers) and diet compositions (cladocerans and decapods vs. phytoplankton and copepods). It is therefore plausible that large phenotypic plasticity and size of the mouth gape (i.e. premaxilla length) of larval $P$. jugularis impacts on the maximum prey size ingested in comparison with larval $P$. chilensis.

In several marine species, gape sizes and allometric relationships to body size are closely associated with maximum prey sizes (Scharf et al. 2000). Similarly, changes to larger prey size during early ontogeny have been observed in a large majority of marine fishes, such as cod Gadus morhua (Rowlands et al. 2008, Swalethorp et al. 2014), anchoveta Engraulis ringens (Llanos-Rivera et al. 2004, Yañez-Rubio et al. 2011) and rockfish Sebastes oculatus (Landaeta et al. 2015). Optimal foraging theory postulates that predators maximize the ratio between the benefits gained and the costs incurred in obtaining prey. The benefits gained increase as a function of prey size, but cost, in particular that due to handling time, also increases rapidly with prey size (Hambright 1991). Additionally, these changes are associated with predator avoidance and the effectiveness of feeding on various types of food (Nunn et al. 2012).

As conclusions during larval development, both species fed on similar prey items, namely copepod nauplii and copepodites, but they differ in terms of mean prey size ingested, which are larger in $P$. jugularis larvae. Finally, diet niche overlap decreases when larval sandperches attain a premaxilla length of around $900 \mu \mathrm{m}$.

\section{ACKNOWLEDGEMENTS}

This research was partially funded by the project Fondecyt 1100424 awarded to Dr F. Patricio Ojeda (Pontificia Universidad Católica de Chile). We appreciate the help of M. Jesús Calderón with lab work and of José E. Bustamante with image processing. The Bioethics Committee, Universidad de Valparaíso, Chile, approved this research. Comments and suggestions of one anonymous reviewer improved an early version of the manuscript.

\section{REFERENCES}

Anderson M.J., Crist T.O., Chase J.M., et al. 2011. Navigating the multiple meanings of $\beta$ diversity: a roadmap for the practicing ecologist. Ecol. Lett. 14: 19-28.

https://doi.org/10.1111/j.1461-0248.2010.01552.x

Aravena G., Broitman B., Stenseth N.C. 2014. Twelve years of change in coastal upwelling along the central-northern coast of
Chile: Spatially heterogeneous responses to climatic variability. PLoS One 9: e90276.

https://doi.org/10.1371/journal.pone.0090276

Arcos D.F., Cubillos L.A., Núñez S. 2001. The jack mackerel fishery and El Niño effects off Chile. Prog. Oceanogr. 49: 597-617. https://doi.org/10.1016/S0079-6611(01)00043-X

Bakun A. 2010. Linking climate to population variability in marine ecosystems characterized by non-simple dynamics: Conceptual templates and schematic constructs. J. Mar. Sys. 79: 361-373. https://doi.org/10.1016/j.jmarsys.2008.12.008

Balbontín F., Llanos A., Valenzuela V. 1997. Trophic overlap and feeding incidence in fish larvae from central Chile. Rev. Chil. Hist. Nat. 70: 381-390.

Bernal-Durán V., Landaeta M.F. 2017. Feeding variations and shape changes of a temperate reef clingfish during its early ontogeny. Sci. Mar. 81(2): 205-215. https://doi.org/10.3989/scimar.04555.09A

Bogacka-Kapusta E., Kapusta A. 2014. Does diet overlap among larval and $0+$ fish species decrease with ontogenetic development? Arch. Pol. Fish 22: 221-228. https://doi.org/10.2478/aopf-2014-0022

Cass-Calay S.L. 2003. The feeding ecology of larval Pacific hake (Merluccius productus) in the California Current region: an updated approach using a combined OPC/MOCNESS to estimate prey biovolume. Fish. Oceanogr. 12: 34-48. https://doi.org/10.1046/j.1365-2419.2003.00206.x

Castro L.R., Salinas G.R., Hernández E.H. 2000. Environmental influences on winter spawning of the anchoveta Engraulis ringens off central Chile. Mar. Ecol. Prog. Ser. 197: 247-258. https://doi.org/10.3354/meps 197247

Corrêa C.E., Hahn N.S., Delariva R.L. 2009. Extreme trophic segregation between sympatric fish species: the case of small sized body Aphyocharax in the Brazilian Pantanal. Hydrobiologia 635: 57-65. https://doi.org/10.1007/s10750-009-9861-2

Cortés E. 1997. A critical review of methods of studying fish feeding based on analysis of stomach contents: application to elasmobranch fishes. Can. J. Fish Aquat. Sci. 54: 726-738. https://doi.org/10.1139/f96-316

Costalago D., Garrido S., Palomera I. 2015. Comparison of the feeding apparatus and diet of European sardines Sardina pilchardus of Atlantic and Mediterranean waters: ecological implications. J. Fish. Biol. 86: 1348-1362. https://doi.org/10.1111/jfb.12645

Cushing D.H. 1990. Plankton production and year-class strength in fish populations: an update of the match/mismatch hypothesis. Adv. Mar. Biol. 26: 249-293. https://doi.org/10.1016/S0065-2881(08)60202-3

Dobroslavić T., Zlatović A., Bartulović V., et al. 2013. Diet overlap of juvenile salema (Sarpa salpa), bogue (Boops boops) and common two-banded sea bream (Diplodus vulgaris) in the south-eastern Adriatic. J. Appl. Ichthyol. 29: 181-185.

Frederich B., Adriaens D., Vandewalle P. 2008. Ontogenetic shape changes in Pomacentridae (Teleostei, Perciformes) and their relationships with feeding strategies: a geometric morphometric approach. Biol. J. Linn. Soc. 95: 92-105. https://doi.org/10.1111/j.1095-8312.2008.01003.x

Gaughan D.J., Potter I.C. 1997. Analysis of diet and feeding strategies within an assemblage of estuarine larval fish and an objective assessment of dietary niche overlap. Fish. Bull. 95: $722-731$.

Genin A., Green C., Haury L., et al. 2004. Zooplankton patchy dynamics: daily gap formation over abrupt topography. Deep Sea Res. I 41: 941-951. https://doi.org/10.1016/0967-0637(94)90085-X

Giesecke R., González H.E. 2008. Reproduction and feeding of Sagitta enflata in the Humboldt Current system of Chile. ICES J. Mar. Sci. 65: 361-370. https://doi.org/10.1093/icesjms/fsn030

Gisbert E., Cardona L., Castelló F. 1996. Resource partitioning among planktivorous fish larvae and fry in a Mediterranean coastal lagoon. Estuar. Coast Shelf Sci. 43: 723-735. https://doi.org/10.1006/ecss.1996.0099

González P., Oyarzún C. 2003. Diet of the Chilean sandperch, Pinguipes chilensis (Perciformes, Pinguipedidae) in southern Chile. J. Appl. Ichthyol. 10: 371-375. https://doi.org/10.1111/j.1439-0426.2003.00444.x

Hambright K.D. 1991. Experimental analysis of prey selection by largemouth bass: role of predator mouth width and prey body depth. Trans. Am. Fish. Soc. 120: 500-508. 
https://doi.org/10.1577/1548-8659(1991)120<0500:EAOPSB> 2.3. $\mathrm{CO} ; 2$

Hammer Ø., Harper D.A.T., Ryan P.D. 2001. Past. Paleontological Statistics Software Package for Education and Data Analysis. Paleontol. Electron. 4: 1-9.

Henríquez L.A., Daneri G., Muñoz C.A., et al. 2007. Primary production and phytoplanktonic biomass in shallow marine environments of central Chile: Effect of coastal geomorphology. Estuar. Coast Shelf Sci. 73: 137-147. https://doi.org/10.1016/j.ecss.2006.12.013

Hernández-Miranda E., Palma A.T., Ojeda F.P. 2003. Larval fish assemblages in nearshore coastal waters off central Chile: temporal and spatial patterns. Estuar. Coast Shelf Sci. 56: 1075-1092. https://doi.org/10.1016/S0272-7714(02)00308-6

Hidalgo P., Escribano R. 2007. Coupling of life cycles of the copepods Calanus chilensis and Centropages brachiatus to upwelling induced variability in the central-southern region of Chile. Prog. Oceanogr. 75: 501-517. https://doi.org/10.1016/j.pocean.2007.08.028

Hidalgo P., Escribano R., Fuentes M., et al. 2012. How coastal upwelling influences spatial patterns of size-structured diversity of copepods off central-southern Chile (summer 2009). Prog. Oceanogr. 92-95: 134-145. https://doi.org/10.1016/j.pocean.2011.07.012

Keast A. 1978. Trophic and spatial interrelationships in the fish species of an Ontario temperate lake. Environ. Biol. Fish. 3: 7-31. https://doi.org/10.1007/BF00006306

Landaeta M.F., Castro L.R. 2012. Seasonal and annual variation in Chilean hake Merluccius gayi spawning locations and egg size off central Chile. Prog. Oceanogr. 92-95: 166-177. https://doi.org/10.1016/j.pocean.2011.07.002

Landaeta M.F., Suárez-Donoso N., Bustos C.A., et al. 2011. Feeding habits of larval Maurolicus parvipinnis (Pisces: Sternoptychidae) in Patagonian fjords. J. Plankton Res. 33: 1813-1824. https://doi.org/10.1093/plankt/fbr081

Landaeta M.F., Bustos C.A., Contreras J.E., et al. 2015. Larval fish feeding ecology, growth and mortality from two basins with contrasting environmental conditions of an inner sea of northern Patagonia, Chile. Mar. Environ. Res. 106: 19-29. https://doi.org/10.1016/j.marenvres.2015.03.003

Llanos-Rivera A., Herrera G., Bernal P. 2004. Food size selectivity and diet overlap in larvae of Clupeiform species from central Chile. Cah. Biol. Mar. 45: 1-8.

Lecomte F., Dodson J.J. 2005. Distinguishing trophic and habitat partitioning among sympatric populations of the estuarine fish Osmerus mordax Mitchell. J. Fish. Biol. 66: 1601-1623. https://doi.org/10.1111/j.0022-1112.2005.00702.x

Loy A., Bertelletti M., Costa C., et al. 2001. Shape changes and growth trajectories in the early stages of three species of the genus Diplodus (Perciformes, Sparidae). J. Morph. 250: 24-33. https://doi.org/10.1002/jmor.1056

Mark W., Hofer R., Wieser W. 1987. Diet spectra and resource partitioning in the larvae and juveniles of three species and six cohorts of cyprinids from a subalpine lake. Oecologia 71: 388-396. https://doi.org/10.1007/BF00378712

Meléndez R. 1989. Alimentación y consideraciones somatométricas de Prolatilus jugularis (Valenciennes) (Teleostei, Branchiostegidae). Bol. Mus. Nac. Hist. Nat. 47: 3-8

Moser H.G. 1996. The early stages of fishes in the California Current Region. California Cooperative Oceanic Fisheries Investigations Atlas $N^{\circ} 33$. Kansas. Allen Press Inc., 1517 pp.

Moreno C.A., Zamorano J.H. 1980. Selectividad del alimento en dos peces bentófagos (Mugiloides chilensis y Calliclinus geniguttatus). Bol. Inst. Oceanogr. Sao Paulo 29: 245-290. https://doi.org/10.1590/S0373-55241980000200051

Neira F.J., Miskiewicz A.G., Trnski T. 1998. Larvae of Temperate Australian Fishes. Laboratory guide for larval fish identification. Nedlands. University of Western Australia Press, 474 pp.

Nunn A.D., Tewson L.H., Cowx I. 2012. The foraging ecology of larval and juvenile fishes. Rev. Fish. Biol. Fish. 22: 377-408. https://doi.org/10.1007/s11160-011-9240-8

Pearre Jr. S. 1986. Ratio-based trophic niche breadths of fish, the Sheldon spectrum, and the size-efficiency hypothesis. Mar. Ecol. Prog. Ser. 27: 299-314. https://doi.org/10.3354/meps027299

Reiss C.S., Anis A., Taggart C.T., et al. 2002. Relationships among vertically structured in situ measures of turbulence, larval fish abundance and feeding success and copepods on Western Bank, Scotian Shelf. Fish Oceanogr. 11: 156-174. https://doi.org/10.1046/j.1365-2419.2002.00194.x

Rosa I.L., Rosa R.S. 1997. Systematic revision of the South American species of Pinguipedidae. Rev. Bras. Zool. 14: 845-865. https://doi.org/10.1590/S0101-81751997000400009

Ross S.T. 1986. Resource partitioning in fish assemblages: a review of field studies. Copeia 1986: 352-388. https://doi.org/10.2307/1444996

Rowlands W.L., Dickey-Collas M., Geffen A.J., et al. 2008. Diet overlap and prey selection through metamorphosis in Irish Sea cod (Gadus morhua), haddock (Melanogrammus aeglefinus), and whiting (Merlangius merlangus). Can. J. Fish. Aquat. Sci. 65: $1297-1306$. https://doi.org/10.1139/F08-041

Russo T., Pulcini D., O’Leary A., et al. 2008. Relationship between body shape and trophic niche segregation in two closely related sympatric fishes. J. Fish. Biol. 73: 809-828. https://doi.org/10.1111/j.1095-8649.2008.01964.x

Salas-Berríos F., Valdés-Aguilera J., Landaeta M.F., et al. 2013. Feeding habits and diet overlap of marine fish larvae from the peri-Antarctic Magellan region. Polar Biol. 36: 1401-1414. https://doi.org/10.1007/s00300-013-1359-8

Scharf F.S., Juanes F., Rountree R.A. 2000. Predator size - prey size relationships of marine fish predators: interspecific variation and effects of ontogeny and body size on trophic niche breadth. Mar. Ecol. Prog. Ser. 208: 229-248. https://doi.org/10.3354/meps208229

Schoener T.W. 1970. Non-synchronous spatial overlap of lizards in patchy habitats. Ecology 60: 703-710.

Sobarzo M., Bravo L., Donoso D., et al. 2007. Coastal upwelling and seasonal cycles that influence on the water column on the continental shelf off central Chile. Prog. Oceanogr. 75: 363-382. https://doi.org/10.1016/j.pocean.2007.08.022

Sun J., Liu D. 2003. Geometric models for calculating cell biovolume and surface area for phytoplankton. J. Plankton Res. 25: 1331-1346. https://doi.org/10.1093/plankt/fbg096

Swalethorp R., Kjellerup S., Malanski E., et al. 2014. Feeding opportunities of larval and juvenile cod (Gadus morhua) in a Greenlandic fjord: temporal and spatial linkages between cod and their preferred prey. Mar. Biol. 161: 2831-2846. https://doi.org/10.1007/s00227-014-2549-9

Valenzuela V., Balbontín F., Llanos A. 1995. Diet composition and prey size of the larvae of eight species of fishes from the coast of central Chile. Rev. Biol. Mar. 30: 275-291.

Vélez J.A., Watson W., Sandknop E.M., et al. 2003. Larval development of the Pacific sandperch (Prolatilus jugularis) (Pisces: Pinguipedidae) from the Independencia Bight, Pisco, Peru. J. Mar. Biol. Ass. UK 83: 1137-1142.

Vera-Duarte J., Landaeta M.F. 2016. Diet of the labrisomid blenny Auchenionchus variolosus (Valenciennes, 1836) (Labrisomidae) during its larval development off central Chile (20122013). J. Appl. Ichthyol. 32: 46-54. https://doi.org/10.1111/jai.12935

Walkusz W., Paulic J.E., Wong S., et al. 2015. Spatial distribution and diet of larval snailfishes (Liparis frabicii, Liparis gibbus, Liparis tunicatus) in the Canadian Beaufort Sea. Oceanologia 58: $117-123$. https://doi.org/10.1016/j.oceano.2015.12.001

Wallace R.K. 1981. An assessment of diet overlap indexes. Trans. Am. Fish. Soc. 100: 72-76 https://doi.org/10.1577/1548-8659(1981)110<72:AAODI> 2.0.CO;2

Yañez-Rubio A., Llanos-Rivera A., Castro L.R., et al. 2011. Variations in type, width, volume and carbon content of anchoveta Engraulis ringens food items during the early larval stages. J. Mar. Biol. Ass. UK 91: 1207-1213.

Zar J.H. 1999. Biostatistical Analysis. Prentice Hall, Upper Saddle River, NJ, 663 pp. 